\title{
DIMENSI ONTOLOGI, EPISTEMOLOGI DAN AKSIOLOGI PENDIDIKAN ISLAM
}

\author{
Fawwaz Noor Amirul Huda \\ Universitas Ahmad Dahlan Yogyakarta
}

Keywords: Ontology, Epistemology, Axiologi,Islamic education

Kata Kunci: Ontologi, Epistemologi, Aksiologi Pendidikan Islam

\begin{abstract}
Philosophy includes five branches of discussion, namely: logic, etestics, ethics, politics and metaphysics. The purpose of this research is to reveal how the meaning and function of the philosophy of science in Islamic education This research is a qualitative research that focuses on library research, using compare, summarize and synthesize approaches. In data source research there are two namely, primary data source and secondary source. The primary sources are books on the philosophy of Islamic education, while the secondary source is books related to the writing of this article. The method used in this research is philosophical analysis method. The results showed that education is the design of philosophy, while philosophy cannot be done without the existence of high science that is only obtained from the process of education. Whereas an advance in science would be easily destroyed if it had ruled out philosophy.
\end{abstract}

\section{ABSTRAK}

Filsafat meliputi lima cabang pembahasan, yaitu: logika, etestika, etika, politika dan metafisika. Tujuan dari penelitian ini adalah mengungkap bagaimana makna dan fungsi filsafat ilmu dalam pendidikan islam . Penelitian ini merupakan penelitian kualitatif yang memfokuskan pada studi kepustakaan (library research), dengan menggunakan pendekatan compare, summarize dan synthesize. Dalam penelitian sumber data ada dua yaitu, sumber data primer dan sumber sekunder. Sumber primernya adalah buku-buku tentang filsafat pendidikan Islam, sedangkan sumber sekundernya adalah buku yang berhubungan dengan penulisan artikel ini. Metode yang digunakan dalam penelitian ini adalah metode analisis filosofis. Hasil penelitian menunjukan bahwa pendidikan merupakan rancangan dari filsafat, sedangkan filsafat tidak dapat dilakukan tanpa adanya ilmu pengetahuan yang tinggi yang hanya didapatkan dari proses pendidikan. Sedangkan sebuah kemajuan ilmu pengetahuan akan rapuh jika mengesampingkan filsafat.

\section{INTRODUCTION}

Berdasarkan sejarahnya filsafat adalah induk dari ilmu (Khojir, 2011), dalam perkembangannya ilmu semakin terspesifikasi, akan tetapi adanya permasalahan kehidupan ini yang tidak dapat dijawab oleh ilmu, maka filsafat menjadi pijakan untuk menjawabnya (Widiawati, 2019). Masalah kehidupan yang tidak bisa dijawab oleh ilmu, maka peran filsafat menjadi tumpuan untuk menjawabnya. Filsafat memberi penjelasan atau jawaban substansial dan radikal atas masalah tersebut(Khojir, 2011) . Sementara ilmu terus berkembang pada wilayahnya, sehingga proses 
tersebut merupakan bidang kajian dari filsafat ilmu, sehingga filsafat ilmu dipandang sebagai usaha untuk menjembatani gap antara filsafat dengan ilmu (Suradi, 2017). Filsafat ilmu adalah kajian filosofis yang berhubungan dengan ilmu, dengan kata lain filsafat ilmu merupakan upaya untuk mengkaji dan mendalami ilmu dari berbagai sudut yaitu pemerolehannya, ciri substansi dan kebermanfaatnanya bagi kehidupan (Chasanah, 2017). Pengkajian filsafat tidak terlepas dari tiga pokok filsafat yang terdiri dari bidang ontologi, epistemologi, dan axiologi dengan berbagai pengembangannya.

Berdasarkan tradisi filsafat zaman Yunani Kuno, pertama kali istilah philosophia dan philosophos ialah Pytagoras tahun 592-497 S.M., yaitu seseorang yang ahli matematika yang lebih dikenal dengan dalilnya tentang geometri. Pytagoras menjelaskan dirinya "philosophos" yang artinya sebagai pencinta kearifan (Halik, 2020). Kearifan yang dimaknai yang dimiliki oleh Tuhan. Penulis sejarah filsafat yaitu bapak dari filsafat yaitu Thales pada tahun 640-546 S.M. mendirikan aliran filsafat kosmos atau alam semesta. Berdasarkan aliran filsafat kosmos, filsafat mreupakan pemaknaan pada alam semesta untuk mengetahui unsur-unsurnya, asal mulanya, dan kaidahkaidahnya (The Liang Gie, 1999). Socrates memaknai filsafat ilmu sebagai sikap seseorang yang mencintai kebijaksanaan dan degan kebijaksanan tersebut mendorong seseorang untuk terus maju, tidak merasa dirinya paling ahli, tidak menyerah pada kemalasan, terus mengembangkan penalaran yang bertujuan untuk mendapatkan kebenaran (Soeparmo, 1984). Lahirnya filsafat disebabkan oleh manusia merasa kagum dan heran, yang diawali dengan kekaguman terhadap gejala alam. Dalam perkembangannya persoalan manusia semakin kompleks, dan dapat dijawab secara keseluruhan dengan filsafat. Jawaban yang dihasilkan menurut (Koento Wibisono, 1997) dengan melakukan refleksi dengan pikirannya sendiri, sehingga, tidak semua persoalan harus persoalan filsafat. Untuk itu penelitian ini akan membahas bagaimana pencarian makna filsafat dalam memecahkan persolan Pendidikan Islam. Dalam perspektif Islam, pendidikan Islam harus berupaya untuk dapat membimbing orang yang memiliki sebuah pemahaman bahwa Allah merupakan sumber kebenran yang obyektif, absolute dan manusia atas dasar fitrah dan mencintai dan berupaya untuk mencari sebuah kebenaran.

\section{METHODS}

Penelitian tentang filsafat ilmu dalam perspektif Pendidikan Islam ini merupakan penelitian literatur. Penelitian literatur sumber datanya diambil berdasarkan buku teks dan jurnal ilmiah yang beriaktan dengan filsafat ilmu dan Pendidikan Islam. Sumber data jurnal berupa jurnal nasional atau internasional yang dapat mendukung penelitian litaratur ini. Untuk memperoleh sumber data yang relevan maka dilakukan pemetaan tema tentang filsafat ilmu dan Pendidikan Islam. Selain itu dipetakan dengan tahun terbitnya sumber data tersebut sebagai upaya mendapatkan data yang 
relevan. Dalam penarikan kesimpulan dilakukan melalui penyajian data dengan mengkonfirmasi kevalidan dan realibiltasnya dengan berbagai sumber.

\section{RESULTS AND DISCUSSION}

Kajian filsafat ilmu yang pertama ialah pada persoalan ontology. Menurut (Baharuddin, 2011)) ontology sering diidentikan dengan metafisika dan juga disebut dengan proto-filsafat atau filsafat yang pertama atau filsafat ketuhanan yang bahasanya ialah hakikat sesuatu, keesaan, persekutuan, sebab dan akibat, realita, prima atau tuhan dengan segala sifatnya, malaikat, relasi atau segala sesuatu yang ada di bumi dengan tenaga yang ada di lanit, wahyu, akhirat, dosa, neraka, pahala dan surge (Baharuddin, 2011).

Epistemologi atau filsafat pengetahuan merupakan sebuah cabang filsafat yang menyelidiki asal mula, susunan, metode dan sahnya sebuah pengetahuan. Menurut (Tobroni, 2015) pembahasan tentang epistimolgi dan pendidikan dibagi menjadi tiga, yaitu: dimensi pengetahuan, sumber pengetahuan dan pengujian kebenaran. Pada dimensi pengetahuan ini sering muncul beberapa pertanyaan, antara lain: apakah realitas dapat diketahui secara sunguh-sunguh? Bagaimana cara mengetahuinya? Tidakkah kebeneran tersebut relatif? Bagaimana relasi pada manusia dengan sebuah pengetahuan? Apakah mansia berperan penting sebagai penerima, partisipan, pengusaha dan penghasil pengetahuan? Apakah ada sebuah pengetahuan yang murni obyektif? Adakah sebuah kebenaran yang bergantung kepada pengalaman manusia?

Dalam perspektif Islam, pendidikan Islam harus berupaya untuk dapat membimbing orang yang memiliki sebuah pemahaman bahwa Allah merupakan sumber kebenran yang obyektif, absolute dan manusia atas dasar fitrah dan hanifnya sangat cinta dan berupaya untuk mencari sebuah kebenaran. Dalam batasan tertentu manusia bisa menjadikan dirinya sebagai sumber pengetahuan, akan tetapi terlepas dari hubungan dengan Allah, sebuah kebenaran yang dipahaminya cenderung bersifat tekstual (Al-Qur'an dan wahyu), tetapi juga fenomena (sebuah kejadian alam) dan faktual (pribadi rasulullah). Sebuah kebenaran yang berbentuk tekstual juga berdasarkan dengan ayat qauliyyah yang terdapat dalam Al-Qur'an dan Hadist, sebuah kebenaran yang fenomenal didasari ayat kauniyah (sunnatullah/sebab-akibat), sedangkan kebenaran yang factual didasari ayat insaniyah yanag terdapat dalam diri manusia khususnya nabi Muhammad sebagai makhluk yang paling utama.

Allah adalah sumber-sumber dari sebuah kebenaran dan pengetahuan. Maka, pendidikan Islam juga harus mendorong orang untuk belajar dari berbagai sumber dari sebuah kebenaran dan menguji sebuah kebenaran tesebut dari prinsip-prinsip sebuah Al-Quran dan Hadist (Tobroni, 2015). Sebagaimana pendapat M. Bahri Ghazali yang dikutip oleh Baharuddin dkk (2010:85), bahwa yang dikatakan "ilmu" merupakan segala sesuatu yang diketahui oleh manusia, pada 
haikatnya berasal dari Allah dan diperoleh manusia yang melalui usahanya sendiri berdasarkan sebuah kekuatan rekayasanya (basyariyah) ataupun sebuah anugerah yang langsung diberikan oleh Allah (mukasyafah).

Baharuddin (2010: 86-87) mengutip pendapat M. Quraish Shihab, ilmu mukasyafah disebut juga 'ilm ladunni, yaitu sebuah ilmu yang diperoleh tanpa upaya manusia. Sedangkan ilmu basyariyah yang disebut juga dengan 'ilm kasbi yaitu sebuah ilmu yang diperoleh karena sebuah usaha manusia yang melakukan pelacakan terhadap suatu kontruksi pada ilmu itu sendiri. Menurut Tobroni (2008: 24), dalam epistimologi, orang dapat menguji suatu kebenaran berdasarkan tiga cara, yaitu: korespondensi, koherensi dan pragmatis. Koredpondensi, sebuah teori ini berpendapat bahwa yang dimaksud dengan sebuah kebenaran ialah sebuah hubungan antara subjek dengan obyek dan tidak ada sebuah pertentangan. Teori korespondensi menekankan persesuaian antara si pengamat dengan apa yang diamati, sehingga sebuah kebenaran yang ditemukan ialah senuah kebenaran empiris. Kelompok ini dinamakan empirisme.

Koheresi dan konsistensi, artinya jika sutau ide, gagasan yang kita miliki dikaji ulang dengan sebuah kriteria penilaian sebelumnya, serta ditelusri dari berbagai segi dan hasilnya ternyata tetap bersesuian, maka hal tersebut mengandung sebuah kebenaran. Teori koherensi menekankan pada suatu peneguhan terhadap ide-ide apriori atau sebuah kebenaran yang logis, yaitu jika proposisiproposisi yang diajukan koheren satu sama lain, kelompok terebut dinamakan rasionalime.

Pragmatis merupakan sebuah nilai dari suatu manfaat dari sebuah pengetahuan atau sebuah kebenaran itu sendiri dalam sebuah kehidupan sehari-hari. Ujian kebenaran dalam filssafat pragmatism merupakan memberikan sebuah manfaat (utility), kemungkinan dapat dikerkjakan (workability) atau sebuah akibat yang dapat memuaskan pada sebuah kemungkinan dan yang benar adalah yang dapat dibuktikan dengan eksperimen (Titus, 1984). Agama Islam mengakui ketiga cara pengujian kebenaran di atas. Sebuah kebenaran ayat-ayat kauniyah (sunnatullah). Sebuah kebenaran yang rasional dalam Islam diakui pada sebuah nalar epsitimologi aqliyah (burhani) dan naqliyah (bayani-irfani), sedangkan pengujian pragmatis dalam Islam diakui bahwa pada ayat-ayat yang mengandung sebuah kebenaran dapat dibuktikan dengan cara eksperimen, bahwa ayat-ayat qauliyyah tidak bertentangan dengan sebuah perkembangan sains dan teknologi.

Aksiologi merupakan sebuah ilmu pengetahuan yang menelidiki pada hakekat sebuah nilai yang pada umumnya ditinjau dari sudut pandang filsafat. Di dunia ini terdapat banyak cabang sebuah pengetahuan yang bersangkutan dengan sebuah problematika yang khusus misalnya ekonomi, etetika, etika, filsafat agama dan epistimologi. Epistemology bersangkutan pada sebuah masalah kebenaran. Sebuah etika bersangkutan pada sebuah masalah keindahan (Kattsoff, 2004). Nilai dan implikasi pada aksiologi di dalam sebuah pendidikan merupakan sebuah pendidikan 
yang menguji dan mengintegrasikan terhadap semua nilai di dalam kehidupan manusia dan membinanya di dalam kepribadian (Husniyah, Nur Iftitahul, 2019).

\section{CONCLUSION}

Dari pembahasan diatas dapat disimpulkan bahwa pertama, permasalahan utama pada filsafat pendidikan Islam ialah tidak jelasnya sebuah akar ontologis. Filsafat pendidikan Islam yang bersumber dari sebuah filsafat. Akan tetapi, sebuah kajian ontologis jika dikaitkan dengan obyek ilmu pendidikan Islam, maka sebuah ilmu dapat dibagi menjadi dua, yaitu ilmu yang bersifat materi dan ilmu yang bersifat non-materi. Kedua, dimensi epistimologi pendidikan Islam, bahwa sebuah ilmu dibagi menjadi dua, yaitu ilmu kasbi dan ilmu mukhasyafah. Selain itu, Islam juga mengakuisumber ilmu yang berasal dari Allah. Ketiga, dimensi aksiologis pendidikan Islam, bahwa sebuah ilmu dipandang dari perspektif kebermanfaatan bagi sebuah kehidupan manusia yang dibagi menjadi dua, yaitu ilmu yang bermanfaat langsung untuk kehidupan. Dimensi ontology, epistemology dan aksiologi merupakan upaya menjalankan kaidah berpikir filsafat sebagai pencarian solusi berbagai persoalan termasuk dalam persoalan pendidikan Islam. Pendidikan Islam yang akan menghadirkanpemikiran utuh tentang pendidikan yang merupakan upaya dalam menemukan berbagai teori tentang pendidikan Islam. Ketiga dimensi filsafat tersebut berfungsi untuk memberikan petunjuk dalam mengembangkan ilmu pendidikan atau pedagogic maupun teori-teori pendidikan baik dari segi ontologi yaitu tujuan, epistemologi yaitu metode, maupun axiologi yang berupa nilai. 


\section{REFERENCES}

Baharuddin, 2010. (2011). Pendidikan Islam Dalam Perspektif Filsafat Ilmu. Hunafa: Jurnal Studia Islamika, 8(1), 53. Retrieved from https://doi.org/10.24239/jsi.v8i1.84.53-80

Chasanah, U. (2017). Ontologi, epistemologi dan aksiologi pendidikan. Tasyri' Jurnal Tarbiyah Syari'ah Islamiyah, 24(1), 76-91.

Halik, A. (2020). Ilmu pendidikan islam: perspektif ontologi, epistemologi, aksiologi. Istiqra', 7(2), 10-24. Retrieved from http://scholar.google.co.id/scholar_url?url=http://jurnal.umpar.ac.id/index.php/istiqra/article/d ownload/500/409\&hl=id\&sa=X\&d=11207406579747201871\&scisig=AAGBfm3_NNvpZzL 0JIvYHKIiFbALxE3FDg\&nossl=1\&oi=scholaralrt\&hist=3MIPFekAAAAJ:88653087186858 7527:AAGBfm

Husniyah, Nur Iftitahul, 2019. (2019). Aksiologis Pendidikan Islam. At-Tuhfah, 8(1), 12-25. Retrieved from https://doi.org/10.36840/jurnalstudikeislaman.v8i1.162

Kattsoff, 2004. (2004). pengantar Filsafat, 228-238.

Khojir. (2011). Membangun Paradigma Ilmu Pendidikan Islam (Kajian Ontologi, Epistemologi Dan Aksiologi). Dinamika Ilmu, 11(1), 1-13. Retrieved from https://journal.iainsamarinda.ac.id/index.php/dinamika_ilmu/article/view/51/50

Suradi, A. (2017). Islamic Education in Facing the Phenomena of Globalization. Al-Idarah: Jurnal Kependidikan Islam, 7(2), 1-22. Retrieved from http://www.ejournal.radenintan.ac.id/index.php/idaroh/article/view/2260

Titus, 1984. (1984). persoalan-persoalaan filsafat. Jakarta.

Tobroni, 2008. (2015). Ilmu Pendidikan Islam dalam Perspektif Filosofis, 03(2), 48-66.

Widiawati, N. (2019). Reformulation of the islamic education philosophy; a study of the epistemological thought of al-farabi. Al-Afkar, Journal For Islamic Studies, 2(1), 48-63. Retrieved from https://doi.org/10.5281/zenodo.3553815

Al-Rasyid, 2005. 2005. "Pendidikan Holistik Dan Tujuan Pendidikan Islam." : 18-39.

Hamzah, Arief Rifkiawan, 2017. 2017. "Konsep Pendidikan Dalam Islam Perspektif Ahmad Tafsir." At-Tajdid : Jurnal Pendidikan dan Pemikiran Islam 1(01): 73-89.

Husniyah, Nur Iftitahul, 2019. 2019. "Aksiologis Pendidikan Islam.” At-Tuhfah 8(1): 12-25.

Nurcholis, Madjid, 2000. 2014. "Konsep Islam Liberal Nurcholis Madjid Dan Implikasinya Terhadap Pendidikan Islam Di Indonesia.” 7: 219-32.

Tolchah, Moch, 20015. 2015. "Filsafat Pendidikan Islam:" Filsafat Pendidikan 11(2): 381-98.

Zakiyah Derajat, 2000. "Pengertian Pendidikan Islam.” : 18-65. 